\title{
Moxidectin as an Endectocide in Reindeer
}

\author{
By A. Oksanen ${ }^{1}$ and M. Nieminen ${ }^{2}$
}

${ }^{1}$ Natıonal Veterınary and Food Research Institute, Regional Laboratory Oulu, and ${ }^{2}$ Finnish Game and Fisherıes Research Institute, Reindeer Research Station, Kaamanen, Finland.

\begin{abstract}
Oksanen A, Nieminen M: Moxidectin as an endectocide in reindeer. Acta vet. scand. 1998, 39, 483-489. - Durıng the winter 1991-92, 42 reindeer hinds of the Kaamanen Experımental Reındeer Herd in Finnish Lapland, naturally infected with various parasites, were allocated to 3 groups. One group was an untreated control group and the other 2 groups received either moxidectın or 1vermectın at a dose of $200 \mu \mathrm{g} \mathrm{kg}^{-1}$ subcutaneously. The efficacy of treatment was followed with monthly faecal examinations for nematode eggs and counting of warbles, Hypoderma tarandi larvae, and throat bots, Cephenemyia trompe larvae, from live animals in spring. The efficacy of moxidectin against warbles $(92.8 \%)$ and throat bots $(70.8 \%)$ did not match that of ivermectin, which was $100 \%$ against both species. Both moxidectın and ivermectın were effective against gastrointestınal trichostrongylid egg production over the December to May trial period indicatıng good efficacy against adult and inhibited trichostrongylids. Only non-signif1cant differences were seen in weight development and calf birth weights between the groups. Because of its only moderate insecticidal efficacy, moxidectin cannot be recommended as an endectocide in reindeer.
\end{abstract}

warbles; throat bots; Hypoderma tarandi; Cephenemyia trompe; trichostrongylids; ivermectin.

\section{Introduction}

Reindeer husbandry in northern Finland has used strategic antiparasitic treatment since the late 1970's. First organophosphates administered systemically were used to control warbles (Hypoderma tarandi larvae) and throat bots (Cephenemyia trompe larvae) and, since the early 1980's, ivermectin has been used (Nieminen 1989). Ivermectin is a synthetic derivative of abamectin, a natural avermectin produced by the actinomycete Streptomyces avermitilis (Shoop et al. 1995). Ivermectin has been shown to perform better than organophosphates against these parasites, as well as being efficacious against various nematodes (Nordkvist et al. 1983) and the pentastomid "sinus worm" Linguatula arctica (Haugerud et al. 1993). Moxidectin is not an avermectin but a member of the milbemycin group. It is synthetically derived from nemadectin, a natural macrocyclic lactone fermentation product of the actinomycete Streptomyces cyaneogriseus ssp. noncyanogenus (Zulalian et al. 1994). Its mode of action is probably similar to that of the avermectins (Shoop et al. 1995). The persistent efficacy of moxidectin was greater than that of ivermectin against ovine trichostrongylids (Taylor et al. 1993) and against induced Dictyocaulus viviparus and Ostertagia ostertagi infections in cattle (Hubert et al. 1995, Barth et al. 1997). Avermectins and milbemycins are called endectocides because of their broad spectrum efficacy against both endo- and ectoparasites (nematodes, insects and arachnids). Due to the high nematocidal potency of mox- 
idectin, it appears to be a good candidate as an endectocide for use in reindeer as the treatments are done durıng winter, when nematode parasites of reindeer may be hypobiotic (Nordkvist et al. 1984). The aim of the present trial was to evaluate the commercial injection formulation (CYDECTIN ${ }^{\circledR} 1 \%$ vet 1 inj, American Cyanamid, now Fort Dodge) of moxidectin in reındeer by comparing its antiparasitıc efficacy with that of the standard treatment, injectable ivermectin. The differences in animal performance, measured as weight development in the treatment groups as well as the birth and autumn weights of calves born to the groups, were also investigated.

\section{Materials and methods}

The trial was initiated on 16 December, 1991, in the Kaamanen Experimental Reindeer Herd $\left(69^{\circ} 09^{\prime} \mathrm{N}, 27^{\circ} 00^{\prime} \mathrm{E}\right)$ in northern Lapland. Forty-two adult reindeer hinds marked with individually numbered collars were weighed and allocated to 3 similar groups according to age. The treatment given to each group was drawn by lot. Group $\mathrm{C}$ was an untreated control group, group $\mathrm{M}$ animals were treated with moxidectin $\left(\right.$ CYDECTIN $^{\circledR} 1 \%$ vet inj., Fort Dodge) at a dose of $200 \mu \mathrm{g} \mathrm{kg}^{-1}$ subcutaneously in front of the left shoulder, and Group I reindeer received ivermectin (IVOMEC ${ }^{\circledR} 10 \mathrm{mg} / \mathrm{ml}$ vet inj, MSD, now Merial) likewise at $200 \mu \mathrm{g} \mathrm{kg}^{-1}$. Following treatment, the animals were observed hourly for adverse reactions during $12 \mathrm{~h}$.

The herd was free-ranging in a fell and pinebirch forest area of 1400 hectares, and it was gathered for weighing and sampling monthly until May. When the animals were collected, faecal samples were taken from rectum. The samples were refrigerated and examined as soon as possible, mostly within 4 days after collection.

Faecal egg counts (FEC) were done according to a modified McMaster method using saturated $\mathrm{NaCl}$ solution with $200 \mathrm{~g}$ sucrose/litre, each egg counted representing 20 eggs per gram (epg). Nematode eggs were identified as trichostrongylid eggs if they were indistinguishable from those of the family Trichostrongylidae: oval or ellipsoid, not markedly asymmetrical, thin-shelled and length 60 to $100 \mu \mathrm{m}$, to the genus Capillaria if they were roughshelled, dark-stained, of barrel shape, length about $50 \mu \mathrm{m}$, and with slightly protruding polar plugs, or to the genus Skrjabinema if they were typical to the genus: about 50 to $70 \mu \mathrm{m}$ long, thin-shelled and markedly asymmetrical (like an orange section). For statistical treatment, all the trichostrongylid faecal egg count values from each individual from January to May were summed up and the sum was divided by the number of samples (5) to get an individual faecal egg count mean value (FECM).

Warbles were counted on May 12 by visual examination and digital palpation. When the amount of warbles exceeded 30 , the count was done in tens, because adjacent warbles might blend together and prevent exact enumeration. Throat bots were counted on May 12 endoscop1cally using a bronchoscope designed for humans (Oksanen et al. 1992b). The amount seen was estimated to the nearest 5 if it exceeded 25 . The hinds were weighed using an ovine balance modified to enable the weighing of reindeer (1 kg reading intervals). The new-born calves were weighed within $24 \mathrm{~h}$ of birth (spring balance, $100 \mathrm{~g}$ intervals). Calves were also weighed in autumn 1992 to elucidate the survival and growth.

Reductions in the respective parasite burden were calculated from the geometric means of parasite numbers in the treated groups compared to the control group, applying the World Association for the Advancement of Veterinary Parasitology (WAAVP) guidelınes (Wood et al. 1995). The significance of difference in num- 
bers of warbles and throat bots, as well as in FECMs between the groups was tested in Kruskal-Wallis one-way analysis of variance. Weight gain differences were statistically tested using the one-way analysis of variance. All statistical analyses were carried out with the Statistix 4.1 analytical software package (Anon. 1994).

\section{Results}

No adverse reactions could be noticed following either of the treatments. During the trial, one animal of the group $\mathrm{M}$ died due to a cause unrelated to the trial, and one animal of the group $\mathrm{C}$ disappeared leaving no trace. Tr1chostrongylid eggs were on December 16 (day 0 ) recorded in low numbers (max. 200 epg) from almost half of the animals in all the groups. The average trichostrongylid FEC remained positive in the control animals throughout the experimental period with peak values ( 170 epg and $\sim 90$ epg) in March and May. After treatment the trichostrongylid FECs became negative in the groups $M$ and I. Subsequently (mostly only after March) they increased at a much slower rate than those of the control group (Fig. 1). The FECMs were significantly different between the groups $(\mathrm{p}<0.001)$ (Table 1 ), with both the treatments causing $>90 \%$ reduction.

Both moxidectin and ivermectin appeared to reduce Capillaria egg production, but the difference in the egg counts was not significant. The geometric mean of Capillaria egg counts also in the control group remained mostly below 2 epg. Skrjabinema eggs were seen in April and May in small numbers in the faeces of a few animals belonging to all of the groups.

In the control group, 12 hinds out of 13 harboured warbles (median intensity 50 , range 8 120). Moxidectin clearly had efficacy against them ( 8 of 12 infected, median intensity 4 , range 2-11). No warbles were found in any of the ivermectin treated animals. The difference in the number of warbles between the groups was statistically significant $(\mathrm{p}<0.001)$. In comparıson of the mean warble ranks, group $\mathrm{C}$ differed $(\mathrm{p}<0.05)$ from groups $\mathrm{M}$ and $\mathrm{I}$.

All 13 of the control group hinds harboured throat bots (median intensity 13, range 2-35). Nine of 12 moxidectin treated animals were infected (median intensity 5.5, range 1-15). No throat bots were found in any of the ivermectin treated animals. The difference in the number of throat bots between the groups was statistically significant $(p<0.001)$; the mean throat bot rank of the I group differed from the other 2 groups.

The mean weight gain between day 0 and day 130 (April 24) was highest and the calf birth weight lowest in the untreated group, however, the difference between the groups was not significant (Table 2). One anımal of the group $\mathrm{C}$ gained $17 \mathrm{~kg}$ and one of the group I lost $11 \mathrm{~kg}$. These 2 animals had a large influence on the mean and s.e.m. for their respective groups.

\section{Discussion}

During the trial winter, trichostrongylid egg output differed from that experienced in other years in the same herd (Oksanen et al 1992a, 1993, Oksanen 1996) in that at the beginning of the trial in December many animals excreted eggs. The egg output of the untreated control group also never reached zero. In March, there was an astounding peak in trichostrongylid egg output of the control group (Fig. 1). There is no readily available good explanation for that.

Moxidectin has been found to be highly efficacious against the most important nematode parasites of cattle and sheep (Ranjan et al 1992, Taylor et al. 1993), as has ivermectin (Campbell \& Benz 1984). In the present trial, both moxidectin and ivermectin showed high efficacy against trichostrongylids in reindeer. 


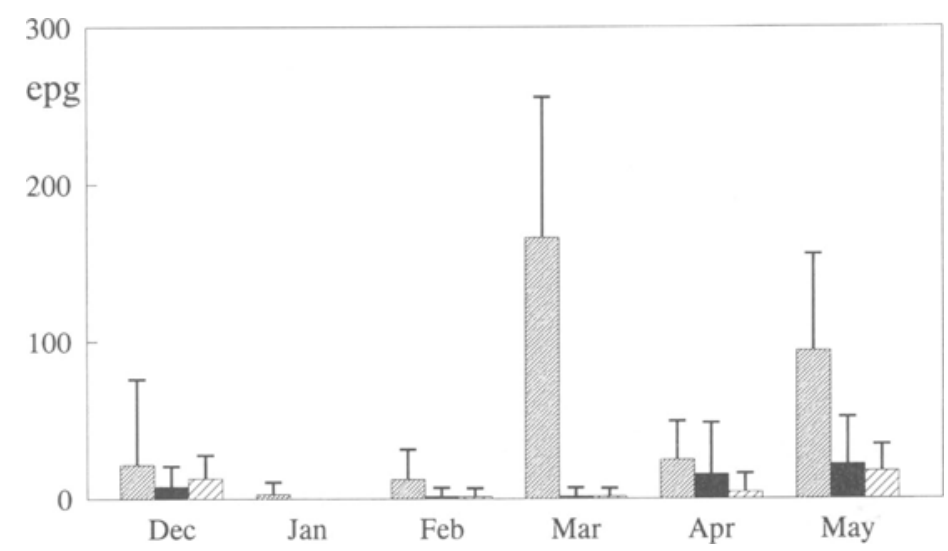

F1gure 1. Mean (standard deviation of the mean) of trichostrongylid egg output of Kaamanen reindeer hinds of control and moxidectin and ivermectın treatment groups, sampled monthly from December 1991 to May 1992. Control, no treatment. Moxidectın subcutaneously $200 \mu \mathrm{g} \mathrm{kg}^{-1}$ on December 16 . Wuाle Ivermectın subcutaneously $200 \mu \mathrm{g} \mathrm{kg}^{-1}$ on December 16 .

Injectable moxidectin was in one trial $96 \%$ effective against first stage larvae of the ovine nasal bot fly Oestrus ovis, but the efficacy against second and third stage larvae was $100 \%$ (Puccini et al. 1994). At the time of treatment in the present trial, obviously all the $C$. trompe were 1st stage larvae (Nilssen \& Haugerud 1995) and thus perhaps least susceptible to treatment, which might have contributed to the low $(70.8 \%)$ efficacy.

Moxidectin has also been reported to have high efficacy against cattle warbles (Scholl et al. 1992, Lonneux \& Losson 1994). In the present trial the efficacy of moxidectin injection against reindeer warbles was $92.8 \%$, which is at the same level as the efficacy of the organophosphate fenthion (Nordkvist et al. 1983). This efficacy might be considered substantial. However, as ivermectin in the present trial, and also in many other experiments (Nordkvist et al. 1983, Oksanen et al. 1992a, 1993, Oksanen 1996) killed $100 \%$ of warbles, moxidectin is definitely not the first choice endectocide. In two trials with horses, oral moxidectin was less efficient against Gasterophilus spp. larvae than oral ivermectın (Xiao et al. 1994, Monahan et al. 1996). While abamectin injection had high efficacy against biting lice, Bovicola bovis, no effect was seen following moxidectin injection (Titchener et al. 1994). The dung from moxidectin treated cattle was also less toxic to various insects than the dung from ivermectin treated cattle (Strong \& Wall 1994). Therefore, it has been claimed that the anthelmintic and acaricidal properties of moxidectın are generally superior to its insecticidal properties (Shoop et al. 1995).

Whether the unsatisfactory efficacy against warbles and throat bots depends solely on the intrinsic lower efficacy of moxidectin against insects, cannot be stated. Moxidectin is also more lipofilic than ivermectin (Hayes 1994), and reindeer during the winter are generally on a negative energy balance consuming their fat reserves. Therefore, it seems possible that another reason for the inadequate efficacy might be in the pharmacokinetics of moxidectin in weight-losing reindeer. Pharmacokinetics of moxidectin in reindeer should be examined before conclusions can be drawn. The efficacy of 
Table 1. Geometric means and efficacy of endectocide treatment against various parasites in Kaamanen reindeer hinds 1991-92. The number of Hypoderma tarandi and Cephenemyla trompe counted in live animals.

\begin{tabular}{lccc}
\hline & \multicolumn{3}{c}{ Group $^{\mathrm{a}}$} \\
\cline { 2 - 4 } Parasite & Control & Moxidectın & Ivermectın \\
\hline Hypoderma tarandl & 39.3 & 2.85 & 0 \\
\% reduction & - & 92.8 & 100 \\
Cephenemyia trompe & 13.7 & 4.0 & 0 \\
\% reduction & - & 70.8 & 100 \\
Trichostrongylid FECM $^{\mathrm{b}}$ & 56.3 & 4.3 & 2.8 \\
\% reduction & - & 92.3 & 95.1 \\
\hline
\end{tabular}

a Control, no treatment. Moxidectin $200 \mu \mathrm{g} / \mathrm{kg}$ on December 16 . Ivermectın $200 \mu \mathrm{g} / \mathrm{kg}$ on December 16 .

b Faecal Egg Count Mean $=($ FEC(Jan) + FEC(Feb) + FEC(Mar) + FEC(Apr) + FEC(May) $) / 5$.

Table 2 Weights $(\mathrm{kg})$ of the reindeer hinds and their calves of the control and treatment groups in Kaamanen 1991-92.

\begin{tabular}{lccc}
\hline & \multicolumn{3}{c}{ Group $^{\mathrm{a}}$} \\
\cline { 2 - 4 } & \multicolumn{1}{c}{ Control } & Moxidectın & \multicolumn{1}{c}{ Ivermectın } \\
\hline Weight Day 0 $^{\mathrm{b}}$ & $75.4(1.9) ; 13^{\mathrm{c}}$ & $76.9(28), 13^{\mathrm{c}}$ & $78.1(2.8), 14$ \\
Growth to Day $130^{\mathrm{d}}$ & $1.8(15) ; 13$ & $1.0(0.8) ; 13$ & $0.8(1.3) ; 14$ \\
Calf birth weight $_{\text {Calf we1ght Sep 18 }}^{\mathrm{e}}$ & $0.5(0.9) ; 12$ & $1.0(0.8) ; 13$ & $1.7(1.0) ; 13$ \\
${\text { Calf we1ght Dec } 14^{\mathrm{f}}}$ & $5.24(0.21) ; 10$ & $5.55(0.25) ; 12$ & $5.63(0.29) ; 11$ \\
& $48.9(3.4) ; 7$ & $50.2(2.1) ; 11$ & $47.6(17) ; 10$ \\
\hline
\end{tabular}

a Control, no treatment. Moxidectin $200 \mu \mathrm{g} / \mathrm{kg}$ on December 16. Ivermectın $200 \mu \mathrm{g} / \mathrm{kg}$ on December 16.

b Mean (standard error of the mean); number.

c The eventually missed two anımals excluded

d Omitting the two extreme values (see text).

e All calves were not found in September due to the herd being spread.

f Some calves were slaughtered in November (normal procedure for the herd).

moxidectin in fattening reindeer in early autumn against warbles and throat bots might also be worth evaluating.

Although the mean weight gain of untreated control animals was highest, this may at least partly be caused by parasite biomass. Typically, a third instar warble weighs $1600 \mathrm{mg}$ (Breyev $1961)$ and it is associated with host tissue reaction. Nordkvist (1967) estimated that warbles alone could make up to $500 \mathrm{~g}$ in one animal. After removal of 2 animals with extreme weight gain or weight loss, there is a weak positive effect of treatment in both weight gain and calf birth weight.

\section{Acknowledgements}

We are very grateful to the personnel of the Kaamanen Experimental Reindeer Herd for competent care of the experimental reindeer. The technical assistance of K. Poulsen and J. Forsbom is also thankfully remembered, as well as that of the staff of the Oulu regional laboratory. We also thank Enc Deroover and Jeff Craven for comments on the manuscript. 


\section{References}

Anononymous Statıstıx ${ }^{\circledR}$ version 4 1. User's manual. Analytical Software, Tallahassee, Fl , 1994.

Barth D, Ericsson GF, Kunkle BN, Rehbein S, Ryan $W G$, Wallace $D H$ Evaluation of the persistence of the effect of ivermectın and abamectın against gastrointestınal and pulmonary nematodes in cattle Vet. Rec 1997, 140, 278-279.

Breyev KA Biological principles of the control of warble-flies. Entomological Review (Washington) $1961,40,36-45$

Campbell WC, Benz $G W$ Ivermectın: a review of efficacy and safety J Vet. Pharmacol. Ther 1984, 7, 1-16.

Craig TM, Hatfield TA, Pankavich JA, Wang GT Efficacy of moxidectın against an ivermectın-resistant strain of Haemonchus contortus in sheep Vet Parasitol. 1992, 41, 329-333

Haugerud RE, Nilssen AC, Rognmo A On the efficacy of ivermectın against the reindeer sinus worm Linguatula arctica (Pentastomida), with a review on ivermectin in reindeer Rangifer 1993, $13,157-162$

Hayes $P W$ Moxidectın understanding the unique persistent anthelmintic activity of this second generation macrocyclic lactone Proceedings AVA (Australian Veterinary Association) Canberra, ACT Australia 6th to 11th March, 1994

Hubert J, Kerboeuf D, Cardinaud B, Blond F Persistent efficacy of moxidectın against Dictyocaulus viviparus and Ostertagia ostertagi in cattle. Vet Rec 1995, 136, 223-224

Lonneux JF, Losson BJ The efficacy of moxidectin $05 \%$ pour-on against Hypoderma bovis in naturally infested cattle parasitological and serological data Vet Parasitol 1994, 52, 313-320.

Monahan CM, Chapman MR, Taylor HW, French $D D$, Kleı TR Comparıson of moxidectın oral gel and ivermectin oral paste against a spectrum of internal parasites of ponies with special attention to encysted cyathostome larvae. Vet Parasitol 1996, 63, 225-235

Nieminen $M$ Loistorjunnan merkitys. (The relevance of antiparasitic treatments ) Poromies 1989 (3), 28-36. (In Finnish).

Nilssen AC, Haugerud RE Epizootiology of the reindeer nose bot fly Cephenemyla trompe (Modeer) (Diptera Oestridae) in reindeer, Rangifer tarandus (L.) in Norway. Can. J Zool. 1995, 73, 10241036

Nordkvist $M$ Treatment experiments with systemic insecticides against the larvae of the reindeer grub fly (Oedemagena tarand $l$ L.) and the remdeer nostril fly (Cephenomyla trompe L ) Nord. Vet Med. 1967, 19, 281-293.

Nordkvist M, Christensson D, Rehbinder C E Ett fältavmasknıngsförsòk med ıvermectın (MSD) på renar (A deworming field trial with ivermectin (MSD) in reindeer ) Rangifer 1984, 4, 10-15

Nordkvist M, Rehbinder C, Christensson D, Ronn$b \dot{a} c k C$ A comparative study on the efficacy of four anthelmintics on some important reindeer parasites Rangifer 1983, 3, 19-38.

Oksanen $A$ Influence of timing of endectocidic antiparasitic treatment on its efficacy in overwintering reindeer. Rangifer 1996, 16, 147-150.

Oksanen A, Nieminen M, Soverı T A comparison of topical, subcutaneous and oral administrations of ivermectın to reındeer Vet. Rec. 1993, 133, 312314

Oksanen A, Nieminen M, Soverı T, Kumpula K. Oral and parenteral administration of ivermectın to reindeer. Vet Parasitol. 1992a, 41, 241-247.

Oksanen A, Soverl T, Nieminen $M$ Fibre-optical pharyngoscopy for diagnosing throat bots in the reindeer Short Communication. Bull. Scand. Soc Parasitol 1992b, 2, 30-32

Puccinı V, Giangaspero A, Fasanella A Efficacy of moxidectın against Oestrus ovis larvae in naturally infested sheep. Vet Rec. 1994, 135, 600601

Ranjan S, Trudeau C, Prichard RK, von Kutzleben R, Carrier $D$ Efficacy of moxidectın against naturally acquired nematode infections in cattle Vet. Parasitol. 1992, 41, 227-231.

Scholl PJ, Gulllot FS, Wang GT Moxidectın' systemic activity against common cattle grubs $(\mathrm{Hy}-$ poderma lineatum) (Diptera. Oestridae) and tr1chostrongyle nematodes in cattle. Vet. Parasitol 1992, 41, 203-209

Shoop WL, Mrozık H, Fisher MH Structure and activity of avermectıns and milbemycins in anımal health Vet. Parasitol 1995, 59, 139-156

Strong $L$, Wall $R$ Effects of ivermectin and mox1dectin on the insects of cattle dung. Bull Entomol Res. 1994, 84, 403-409

Taylor SM, Edgar H, Kenny J Prophylactic efficacy of moxidectın for periparturient ewes and midsummer lambs Vet. Rec. 1993, 133, 270-271.

Titchener RN, Parry JM, Grimshaw WTR Efficacy of formulations of abamectın, ivermectın and moxidectın against sucking and bitıng lice of cattle. Vet Rec 1994, 134, 452-453.

Wood IB, Amaral NK, Bairden JL, Duncan JL, Kas- 
sal T, Malone JB, Pankavich JA, Reınecke RK, Slocombe O, Taylor SM, Vercruysse J. World Association for the Advancement of Veterinary Parasitology (W.A.A.VP.) second edition of guidelines for evaluatıng the efficacy of anthelmintics in rumınants (bovıne, ovıne, caprıne). Vet. Parasitol 1995, 58, 181-213

Xıao L, Herd RP, Majewskı GA C Comparatıve efficacy of moxidectin and ivermectin against hypobiotic and encysted cyathostomes and other equine parasites. Vet. Parasitol 1994, 53, 83-90.

Zulalian J, Stout SJ, daCunha AR, Garces T, Miller $P$ Absorption, tissue distribution, metabolism, and excretion of moxidectin in cattle. J Agric Food Chemistry 1994, 42, 381-387.

\section{Sammendrag \\ Moxıdektın som endektosid 1 rein}

I desember 1991 ble 42 reınsdyrsımler fra Kaamanen forsøksflokk delt 1 tre grupper En gruppe var ubehandlet, mens de to andre gruppene ble behandlet subkutant enten med moxidektın eller ivermektın med dose $200 \mu \mathrm{g} \mathrm{kg}^{-1}$ Effekten av behandlıngen ble vurdert etter månedlige fæcesundersøkelser for nematode-egg tıl ma1 (1992) og etter tellıng av hud- og nesebremslarver (Hypoderma tarandl og Cephenemyı trompe) Moxidektın hadde lavere effekt mot hud- og nesebremslarver (92.8\% respektıve $708 \%)$ enn 1vermektın (100\% mot begge arter) Både mox1dektın og ivermektın hadde høg effekt mot eggproduksjon av gastro-intestınale trıchostrongylıder, hvilket indiserer høg effekt mot både voksne og inhiberte trichostrongylıder. Det var 1kke sıgnifikante forskjell mellom vektutviklıng hos simler eller fødselsvekter hos kalver.

(Recelved Aprll 6, 1998, accepted September 14, 1998)

Reprints may be obtained from. A. Oksanen, Norwegıan College of Veterınary Medicıne, Department of Arctıc Veterınary Medicıne, N-9005 Tromsø, Norway. E-mail: Antt1.Oksanen@veths.no, tel: +47 77665413, fax: +4777684411 . 
